\title{
Pentalogy of Cantrell: the complete spectrum
}

\author{
Cátia Filipa Martins, ${ }^{1}$ Inês Serras, ${ }^{2}$ Ana Vanessa Santos, ${ }^{3}$ Ana Costa Braga ${ }^{4}$
}

${ }^{1}$ Department of GynecologyObstetrics, Centro Hospitalar do Algarve, Portimão, Portugal ${ }^{2}$ Department of Pediatrics, Centro Hospitalar do Algarve, Portimão, Portugal

${ }^{3}$ Department of GynecologyObstetrics, Hospital Fernando Fonseca, Amadora, Portugal ${ }^{4}$ Department of Anatomic Pathology, Centro Hospitalar Lisboa Ocidental, Lisboa, Portugal

\section{Correspondence to} Dr Cátia Filipa Martins, paixaocatia@gmail.com

Accepted 26 October 2014

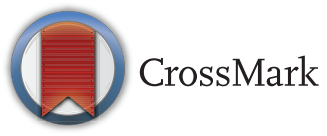

To cite: Martins CF, Serras I, Santos AV, et al. BMJ Case Rep Published online: [please include Day Month Year] doi:10.1136/ bcr-2014-207556

\section{DESCRIPTION}

A healthy 25-year-old primigravida, without a history of teratogenic exposition, presented to our hospital with a first trimester routine ultrasonographic examination showing two major fetal defects: gastrosquisis (figure 1 and video 1 ) and ectopia cordis (video 2). At 16 weeks of gestation a detailed ultrasound confirmed the suspected abnormalities together with sternal and diaphragm defects, and pentalogy of Cantrell was suspected. An amniocentesis and termination of the pregnancy were considered and

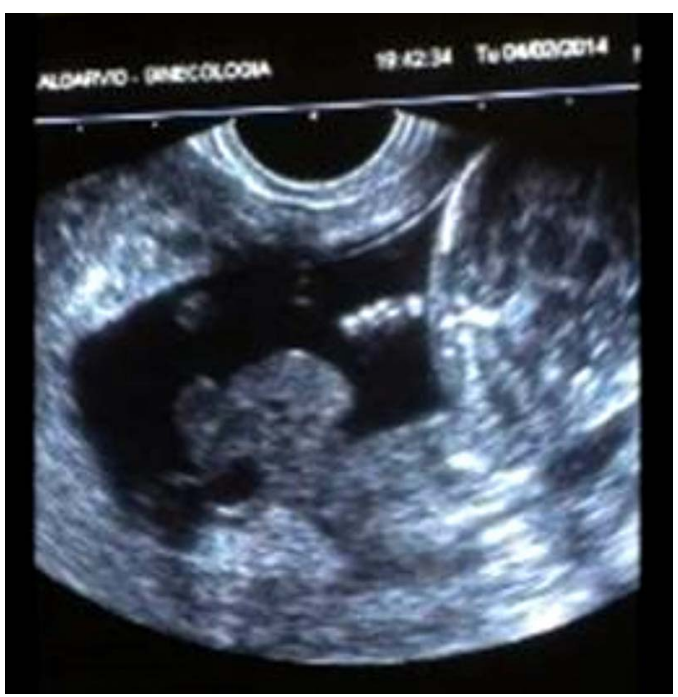

Figure 1 Ultrasound at 14 weeks revealing gastrosquisis.

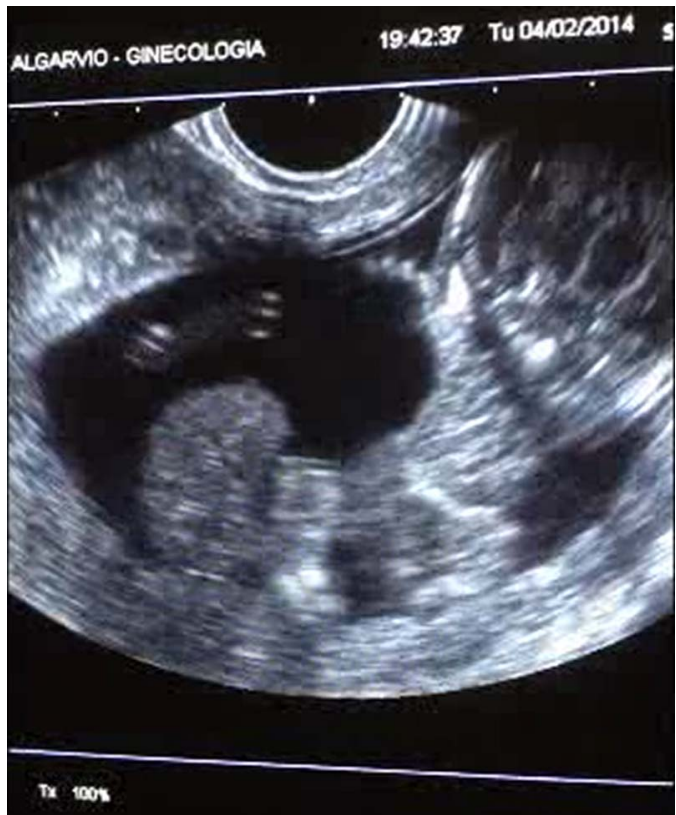

Video 1

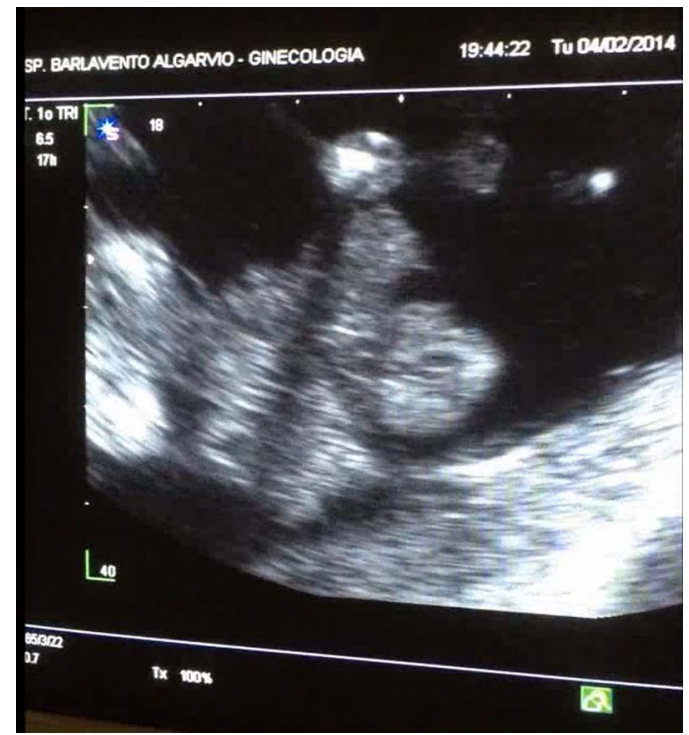

Video 2

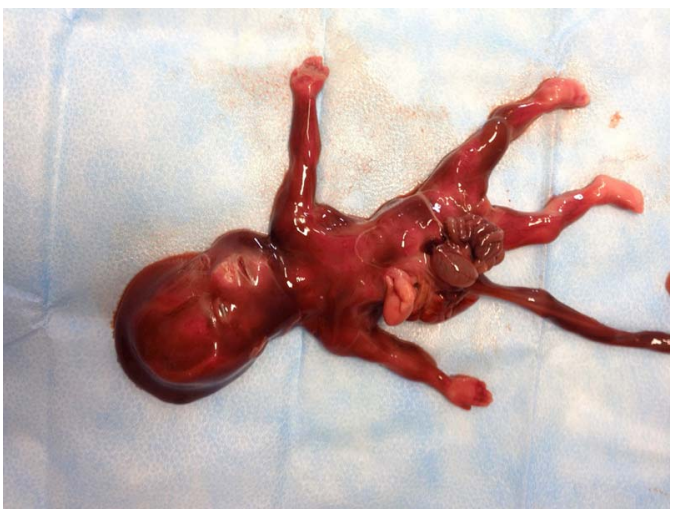

Figure 2 Delivered dead fetus.

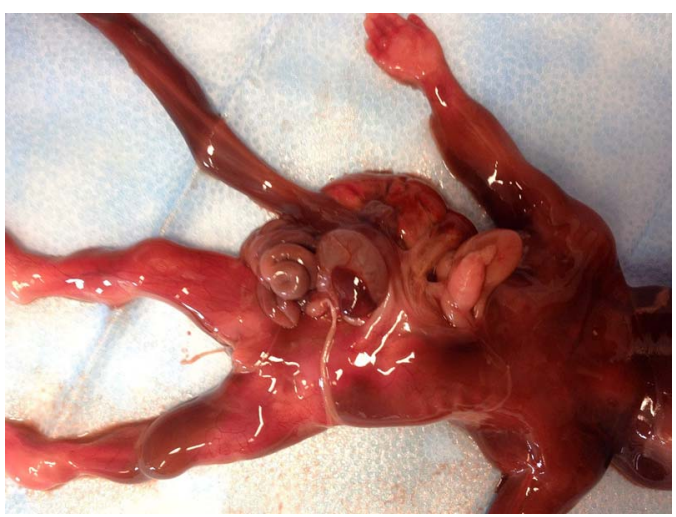

Figure 3 Thoracic defect with ectopia cordis plus abdominal wall defect with severe gastrosquisis: liver, stomach, intestines and spleen. 


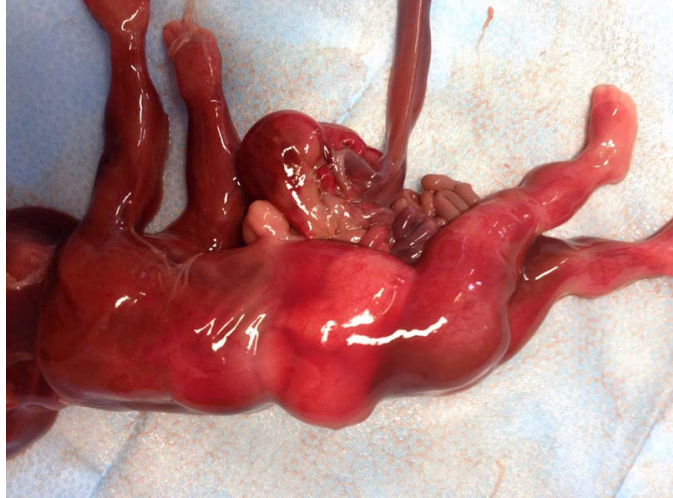

Figure 4 Ectopia cordis and severe gastrosquisis.

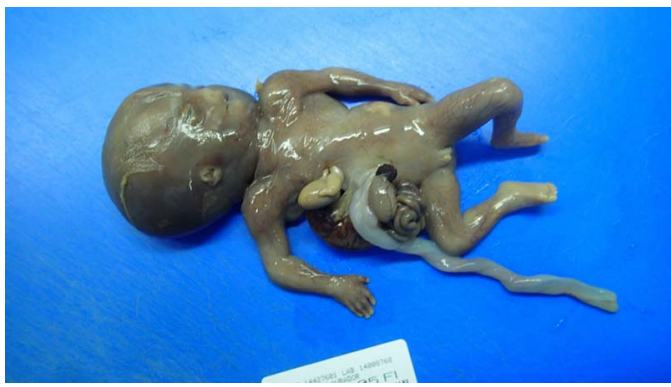

Figure 5 Anatomopathological examination of the fetus.

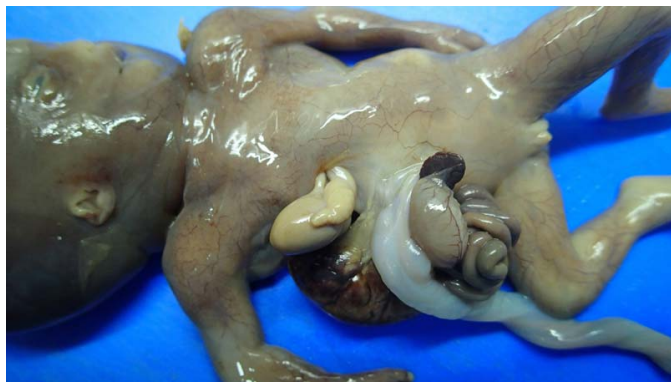

Figure 6 Anatomopathological examination of the fetus.

accepted by the couple. After expulsion, we identified a dead fetus (figure 2) weighing $113 \mathrm{~g}$, with a thoracoabdominal wall defect with ectopia cordis and evisceration of stomach, liver, intestines and spleen (figures 3 and 4). The anatomopathological examination (figures 5 and 6) recognised additional cardiac defects, which provided the final diagnosis of pentalogy of Cantrell: absent pericardium and diaphragm, lower sternal defect, transposition of great vessels, severe right ventricle hypoplasia, enlarged left cavities and intraventricular communication. No other malformations or chromosomal abnormalities were documented. First described in 1958 by Cantrell, pentalogy of Cantrell (OMIM 313850) is an extremely rare and usually lethal congenital malformation, with an estimated incidence from 5.5 to 7.9 per million live births. The full spectrum is rarely reported and consists of five anomalies: anterior abdominal wall defect, anterior diaphragmatic hernia, sternal cleft, ectopia cordis and intracardiac abnormalities. ${ }^{1} \mathrm{~A}$ possible pathogenesis involves a defect in the differentiation of the intraembryonic mesoderm between 14 and 18 days after conception, so a first trimester ultrasonography is indispensable for the prenatal diagnosis. ${ }^{2}$ Prognosis is poor, depending on the extent of the defects. Few live births of the complete pentalogy have been described. ${ }^{3}$

\section{Learning points}

- The hallmark of this syndrome is ectopia cordis with anterior abdominal wall defect. In the presence of these abnormalities, obstetricians should consider pentalogy of Cantrell.

- Cantrell's syndrome can be diagnosed as early as the first trimester using a two-dimensional (2D) ultrasound. A 3D ultrasound can help to enhance the visualisation of the fetal anomalies.

- Pentalogy of Cantrell must be adequately evaluated for appropriate prenatal counselling and postnatal management of individual cases. Survival depends on the number and severity of the defects so an early diagnosis gives the parents an option of termination of pregnancy.

\section{Competing interests None.}

Patient consent None.

Provenance and peer review Not commissioned; externally peer reviewed.

\section{REFERENCES}

1 Cantrell JR, Haller JA, Ravitch MM. A syndrome of congenital defects involving the abdominal wall, sternum, diaphragm, pericardium, and heart. Surg Gynecol Obstet 1958;107:602-14.

2 Ghinidi A, Sirtori M, Romero R, et al. Prenatal diagnosis of pentalogy of Cantrell. J Ultrasound Med 1988;7:567-72.

3 van Hoorn JH, Moonen RM, Huysentruyt CJ, et al. Pentalogy of Cantrell: two patients and a review to determine prognostic factors for optimal approach. Eur J Pediatr 2008:167:29-35.

Copyright 2014 BMJ Publishing Group. All rights reserved. For permission to reuse any of this content visit http://group.bmj.com/group/rights-licensing/permissions.

BMJ Case Report Fellows may re-use this article for personal use and teaching without any further permission.

Become a Fellow of BMJ Case Reports today and you can:

- Submit as many cases as you like

- Enjoy fast sympathetic peer review and rapid publication of accepted articles

- Access all the published articles

- Re-use any of the published material for personal use and teaching without further permission

For information on Institutional Fellowships contact consortiasales@bmjgroup.com

Visit casereports.bmj.com for more articles like this and to become a Fellow 